\title{
Degradation of diesel and phenol using bacteria isolated from petroleum hydrocar- bon contaminated soil
}

\author{
F. Ahmed, A. N. M. Fakhruddin* and M. M. Kabir \\ Department of Environmental Sciences, Jahangirnagar University, Dhaka-1342, Bangladesh
}

\begin{abstract}
In the present investigation, diesel degrading bacteria were isolated from petroleum hydrocarbon contaminated soil and evaluated their degradation potentials of diesel and phenol at various concentrations. Total hydrocarbon was identified by extracting mixed standard sample (MSS) method from the contaminated soil and scanning wavelength from 190 to $280 \mathrm{~nm}$ by means of UV-visible spectrophotometer. The absorption peak of MSS solution dissolved in hexane was stable at $215 \mathrm{~nm}$ to $230 \mathrm{~nm}$. The average number of diesel degrading bacteria in the soil sample was $2.52 \times 10^{3}$ at $32{ }^{\circ} \mathrm{C}$ for 72 hours. One of the representative isolates was used to degrade diesel at varying amount. At $24 \mathrm{~h}$ of incubation, bacterial growth increased up in $20 \%(\mathrm{v} / \mathrm{v})$ of diesel but in $25 \%(\mathrm{v} / \mathrm{v})$ of diesel bacterial growth decreased. This isolate completely degraded $50 \mathrm{mg} / \mathrm{L}$ phenol after $96 \mathrm{~h}$ of incubation from the culture medium. The isolated bacteria can be used as an effective candidate for bioremediation of diesel and phenol from the hydrocarbon contaminated environments.
\end{abstract}

Keywords: Biodegradation; Phenol; Diesel; Petroleum hydrocarbons; Bacteria

\section{Introduction}

Petroleum hydrocarbons are considered as one of the worst environmental pollutants of the current world because of its devastating consequences to the environment and human health. Large-scale use and accidental release of petroleum hydrocarbons caused serious environmental damages (Ahmed et al., 2010). The release of these hydrocarbons in nature mostly occurs during transportation. Garages and automobile workshops are the major sources of hydrocarbons discharging into the environment by their washing and repairing activities. Apart from this, used engine oil renders the environment unsightly and constitutes a potential threat to humans, animals and vegetation (Usha et al., 2015). It threatens the biodiversity and total ecosystem of an area (UKHPA, 2006).

Diesel is a complex mixture of chemicals mainly obtained from the distillation of crude oil. Breathing large quantities of diesel vapour or drinking diesel-based fluids may cause nonspecific signs and symptoms of poisoning such as dizziness, headache and vomiting. A severe form of lung damage called pneumonitis may occur if liquid diesel is inhaled directly into the lungs (UKHPA, 2006). Phenol is also a hazardous hydrocarbon like diesel. Phenol of anthropogenic origin exists in the environment due to the activity of the chemical, petrol, tinctoral or pharmaceutical industries. Phenol has high toxicity to most of the microorganisms, plants, fish and animals which can cause considerable damage to the environment. It is a potential human carcinogen and is of considerable health concern, even at a low concentration (Naresh et al., 2012). A wide variety of microorganisms have been reported to degrade diesel oil and phenol and completely mineralize them. A few examples are Bacterial genus: Bacillus sp. (Ahmed et al., 2010; Al- Saridah et al., 1999; Singh et al., 2007; Kebria et al., 2009), Pseudomonas sp. (Ahmed et al., 2010; Hong et al., 2004; Ueno et al., 2007; Saadoun, 2002), Citrobacter sp. (Ahmed et al., 2010; Singh et al., 2007), Acinetobacter sp. (Singh et al., 2008) and some fungi like Fusarium sp. (Dhar et al., 2014), Candida sp. (Miranda et al., 2007), Ulocladium sp. (Binsadiq et al., 2014) etc. Some phenol degrading bacteria are Pseudomonas sp. (El-Sayed et al., 2003; Annadurai et al., 2007; Tambeker et al., 2012), Bacillus sp. Banerjjee et al., 2010; Banerjjee and Ghoshal, 2010; Arutchelven et al., 2006), Burkholderia sp. (El-Sayed et al., 2003), Oenococcus sp. and Lactobacillus sp. (Campos et al., 2002) etc. The present study was conducted to determine the physical and chemical parameters of petroleum hydrocarbons contaminated soil from a combined automobile workshop and garage in Noyarhat, Savar, Dhaka, Bangladesh in order to assess the magnitude of hydrocarbons pollution. The present study also aimed to isolate diesel oil degrading bacteria and to evaluate the degradation studies of diesel and phenol by the isolated bacteria. 


\section{Materials and methods}

\section{Collection of soil samples}

Soil samples were collected for total hydrocarbon determination at depth 5 to $10 \mathrm{~cm}$ from a combined workshop and garage area at Noyarhat, Savar, Dhaka. Approximately, 1 $\mathrm{kg}$ of soil was collected and kept in polyethylene bags. The collected soil samples were dried in sun, grounded and passed through a $2 \mathrm{~mm}$ sieve. The sieved soil samples were taken into sample bags, tagged and preserved for analysis. For the isolation of microorganisms, soil samples were collected from the same area. These soils were stored in sterile plastic bags. The samples were transferred to the laboratory as early as possible for microbiological analysis.

\section{Determination of soil physico-chemical properties}

The physical properties of soil (moisture content and soil porosity) and chemical properties $(\mathrm{pH}$ and Electric conductivity) were determined.

\section{Determination of total hydrocarbon from contaminated soil}

Total hydrocarbon was extracted and separated from the contaminated soil and it is referred to hydrocarbon mixed standard sample (MSS). For the preparation of MSS from contaminated soil, $30 \mathrm{gm}$ of soil sample was initially weighed and taken in a $100 \mathrm{ml}$ clean volumetric flask. Then $60 \mathrm{ml}$ of hexane was added to the soil sample. The volumetric flasks were placed in an ultrasonic bath for one hour. Then, the flask was kept at room temperature in an incubator (ModelB-28\#03-43868, Binder, Germany) for $24 \mathrm{~h}$. After incubation, the soil was precipitated and the organic suspension remained as a supernatant. Finally, the supernatant was separated and placed it on a hotplate at $120^{\circ} \mathrm{C}$ for 15 minutes. The residue was referred as MSS (Wang et al., 2011). The UV absorption peak of the MSS was identified by dissolving organic solvents. $2 \mathrm{mg}$ of MSS was dissolved with $10 \mathrm{ml}$ of hexane and scanned wavelength from 190 to $280 \mathrm{~nm}$ by using the UV-visible spectrometer and maximum absorption wavelength was identified (Wang et al., 2011).

\section{Culture Media}

Mineral salt medium (MSM) was used in both isolation of bacteria from soil and diesel and phenol degradation studies, contained $(\mathrm{g} / \mathrm{l})\left(\mathrm{NH}_{4}\right)_{2} \mathrm{SO}_{4}, 2.0 ; \mathrm{KH}_{2} \mathrm{PO}_{4}, 1.5 ; \mathrm{Na}_{2} \mathrm{HPO}_{4}, 1.5$; $\mathrm{MgSO}_{4} \cdot 7 \mathrm{H}_{2} \mathrm{O}, 0.2 ; \mathrm{CaCl}_{2} \cdot 2 \mathrm{H}_{2} \mathrm{O}, 0.01 ; \mathrm{FeSO}_{4} 7 \mathrm{H}_{2} \mathrm{O}, 0.001$. The $\mathrm{pH}$ of the medium was adjusted to $7.0 \pm 0.1$ with $2 \mathrm{M}$ $\mathrm{NaOH}$. Diesel was collected from a local filling station.

\section{Enrichment of soil samples}

In this step of enrichment procedure, MSM was used. $10 \mathrm{gm}$ of collected soil samples were mixed with $100 \mathrm{ml}$ of mineral salt medium containing $10 \%(\mathrm{v} / \mathrm{v})$ diesel as the carbon source in conical flasks. Before mixing the soil samples and diesel, MSM was autoclaved and $\mathrm{pH}$ maintained at $7 \pm 0.5$. The conical flasks were then taken in shaker incubator and incubated at $32^{\circ} \mathrm{C}$ at $100 \mathrm{rpm}$ for 24-48 h (Singh et al., 2008). After incubation, the aliquot of contaminated soil suspension was taken for isolation of bacteria.

\section{Isolation of diesel resistant bacteria from soil}

After enrichment of soil samples, a culture media was prepared where spread plate technique was applied for the isolation of diesel resistant bacteria from contaminated soil. 1 $\mathrm{ml}$ of enriched sample was taken in a test tube and $9 \mathrm{ml}$ sterile water was added and vortex. Subsequently, $0.1 \mathrm{ml}$ of the suspension was added to the agar plate and $100 \mu 1$ of diesel was covered As a sole carbon source. Plates were incubated at $32{ }^{\circ} \mathrm{C}$ for $24-72 \mathrm{~h}$ (Singh et al., 2008). Morphologically distinct colonies were then selected for purification and further studies.

\section{Quantification of diesel resistant bacteria}

After incubation of $48 \mathrm{~h}$ and $72 \mathrm{~h}$, the colonies were counted. The total number of bacteria per gram of soil was then counted by viable plate count method. The quantification of bacteria was done by following formula.

Number of cells $/ \mathrm{ml}=$ number of colonies on plate $\times$ dilution factor $\times$ fraction of $\mathrm{ml}$ plated

\section{Purification of the isolates}

The isolated organisms were purified through repeated subculture method. Streak plate methods were used for this purpose. MSM and agar were used as media. When a plate yielded only one type of colony, the organisms were considered to be pure. For the preservation of the organisms, the agar plate containing single purified colonies were kept in the refrigerator at $4{ }^{\circ} \mathrm{C}$ and short-term preservation was performed.

\section{Identification of isolate}

Morphological studies were carried out to determine the cultural characteristics of bacteria to identify and classify organisms into taxonomic groups. The purified colonies were sub- cultured in MSM media. Isolates were grown on MSM media and agar separately and incubated at $32{ }^{\circ} \mathrm{C}$ for $24 \mathrm{~h}$. The Gram staining method was carried out.

Effect of various concentrations of diesel on growth of microorganisms

The isolated bacteria from diesel contaminated soil was grown in MSM media which containing a varying 
concentration of diesel as a carbon source. One of the purified potential isolate grown on the agar plate was taken by using a sterile loop in sterile water in a test tube. The test tube was then vortex and a suspension of the cell was prepared. The equal amount of suspension (one $\mathrm{ml}$ of each) was then taken into five conical flasks containing 5\%,10\%, 15\%, 20\% and $25 \%$ (v/v) diesel with MSM media. Another conical flask was used as control that contained only MSM media and diesel. All the conical flasks were then taken in a shaker incubator and incubated at $32{ }^{\circ} \mathrm{C}$ at $100 \mathrm{rpm}$ for $24 \mathrm{~h}$. The effect of varying concentrations of diesel on bacterial growth was measured by monitoring optical density (OD) at $600 \mathrm{~nm}$.

\section{Assay of Phenol}

Phenol concentrations were determined by using the 4-aminoantipyrene colorimetric method based on the procedure detailed in Standard Methods for the Examination of Water and Wastewater (APHA, 1998).

\section{Assay procedure}

Samples were taken into the test tube at a regular time interval. Then $200 \mu 1$ of supernatant were taken through micropipette and added with $9.8 \mathrm{ml}$ distilled water and mixed well with a vortex mixer (Model- VM-1000). At first $250 \mu 1$ of $0.5 \mathrm{~N} \mathrm{NH}_{4} \mathrm{OH}$ was added to each Test tube and mixed well. The $\mathrm{pH}$ was adjusted to $7.9 \pm 0.1$ by using potassium phosphate buffer ( $\mathrm{pH}$ 6.8). $100 \mu \mathrm{l}$ of 4-aminoantipyrene solutions $(2 \% \mathrm{w} / \mathrm{v})$ and $100 \mu \mathrm{l}$ potassium ferricyanide $(8 \%$ $\mathrm{w} / \mathrm{v}$ ) were added in each test tube and mixed well. In one test tube, $10 \mathrm{ml}$ distilled water was taken which was used to eliminate the effect of assay reagents from the control that contained phenol only. The Test-tube were allowed to complete reaction at room temperature for 15 minutes and the absorbance was taken at $500 \mathrm{~nm}$ using UV-Visible Spectrophotometer (Model- Spectrumlab 1200RS, Japan). The spectrophotometer was first made auto zero using blank to eliminate the effect of assay reagents. A standard calibration curve was prepared with the concentration of phenol in the range of 0-5 ppm. The absorbance was recorded on spectrophotometer and corresponding phenol concentrations was determined by using this standard curve.

Effect of various concentrations of both phenol and diesel on growth of isolate

The effect of varying concentrations of both phenol and diesel on the bacterial growth was measured. One of the purified potential isolate grown on the agar plate was taken by using a sterile loop in sterile water in a test tube. The test tube was then vortex and a suspension of cell was prepared. The equal amount of suspension (one ml of each) was then taken into four conical flasks containing MSM media and different concentration of phenol and diesel. All the conical flasks were then taken in a shaker incubator and incubated at $32{ }^{\circ} \mathrm{C}$ at $100 \mathrm{rpm}$ for $24 \mathrm{~h}$. The effect of varying concentrations of diesel and phenol on the microbial growth was measured by monitoring optical density (OD) at $600 \mathrm{~nm}$.

\section{Results and discussion}

\section{Physical and chemical parameters}

The values of physical parameter (moisture content and porosity) and chemical parameter ( $\mathrm{pH}$ and EC) of the soil samples are presented in Table I. The result of soil physical parameters shows that the tested samples contain moisture content in the range of $13.71 \%$ to $21.33 \%$. The porosity of soil ranges from $41.45 \%$ to $45.63 \%$. The moisture content of the soil was lower in the soil samples though the sampling was done in the rainy season. Therefore, the presence of hydrocarbons in the contaminated soil may be the reason for the low moisture content in the sampled soils. $\mathrm{pH}$ of the studied soil was approximately neutral. The electric conductivity of soil ranges from $970 \mu \mathrm{S} / \mathrm{cm}$ to $2760 \mu \mathrm{S} / \mathrm{cm}$. The greater the total soil porosity, the more easily it conducts electricity. But in this study highest porosity found in S-2 and highest EC found in S-4. Increased concentrations of oil-derivative compounds in soil modify the soil's physical

Table I. Physico-chemical parameters of hydrocarbon contaminated soil

\begin{tabular}{ccccc}
\hline Sample ID & Moisture content $(\%)$ & Porosity $(\%)$ & $\mathrm{pH}$ & $\mathrm{EC}(\mu \mathrm{S} / \mathrm{cm})$ \\
\hline S-1 & 13.71 & 41.45 & 7.32 & 1400 \\
S-2 & 16.22 & 43.86 & 7.37 & 2120 \\
S-3 & 19.17 & 43.08 & 7.84 & 2760 \\
S-4 & 21.33 & 45.63 & 7.39 & 2710 \\
S-5 & 18.31 & 42.2 & 7.49 & 970 \\
\hline
\end{tabular}


and chemical properties (Kucharski et al., 2010). Therefore, the correlation of EC with the porosity has changed because of the presence of hydrocarbon in soil samples.

\section{Detection of total hydrocarbon in Soil samples}

The UV absorption peak of MSS was identified after dissolving it in a common organic solvent hexane and by scanning wavelength from 190 to $280 \mathrm{~nm}$ which is presented in Fig. 1. It was demonstrated that the absorption peak was maximum at $215 \mathrm{~nm}$ to $230 \mathrm{~nm}$. Wang et al., (2011), proposed this method in a hydrocarbon contaminated soil that derived from a drum washing factory. This method was based on an assumption that the possibly extracted total
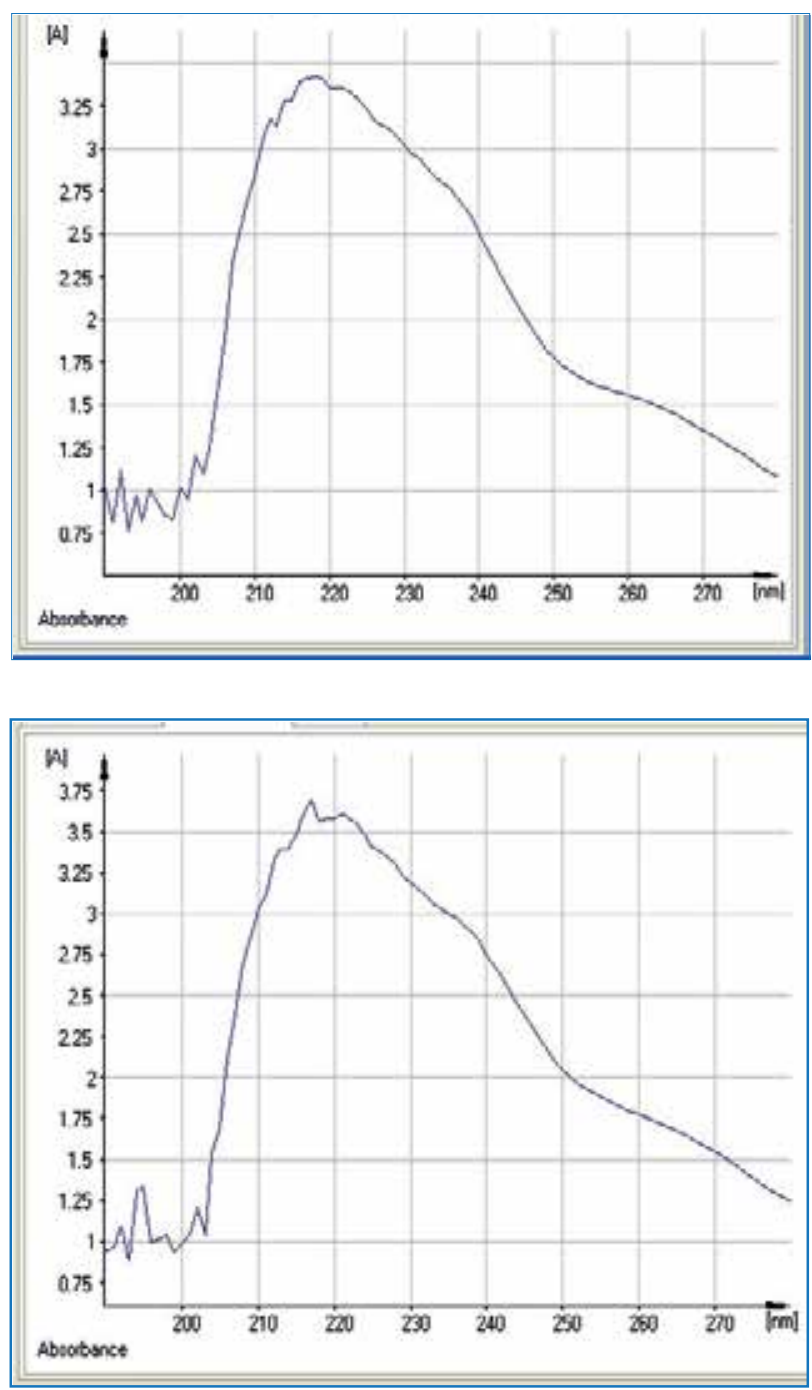

hydrocarbon by organic solvent in the hydrocarbon mixture-contaminated soil had an ultraviolet absorption peak and could be used as hydrocarbon mixture standard sample (MSS), by which total hydrocarbon content in the contaminated soil could be measured using ultraviolet spectrophotometry instead of traditional analysis methods (GC, HPLC, GC-MS and HPLC-MS).

\section{Isolation and characterization of diesel degrading bacteria}

The total number of diesel degrading bacteria is presented in Table II. The range of total number of diesel degrading bacteria in soil samples was $7.0 \times 10^{2} \mathrm{CFU} / \mathrm{gm}$ to $2.35 \times 10^{3}$ at 48 hours and the total number of diesel degrading bacteria
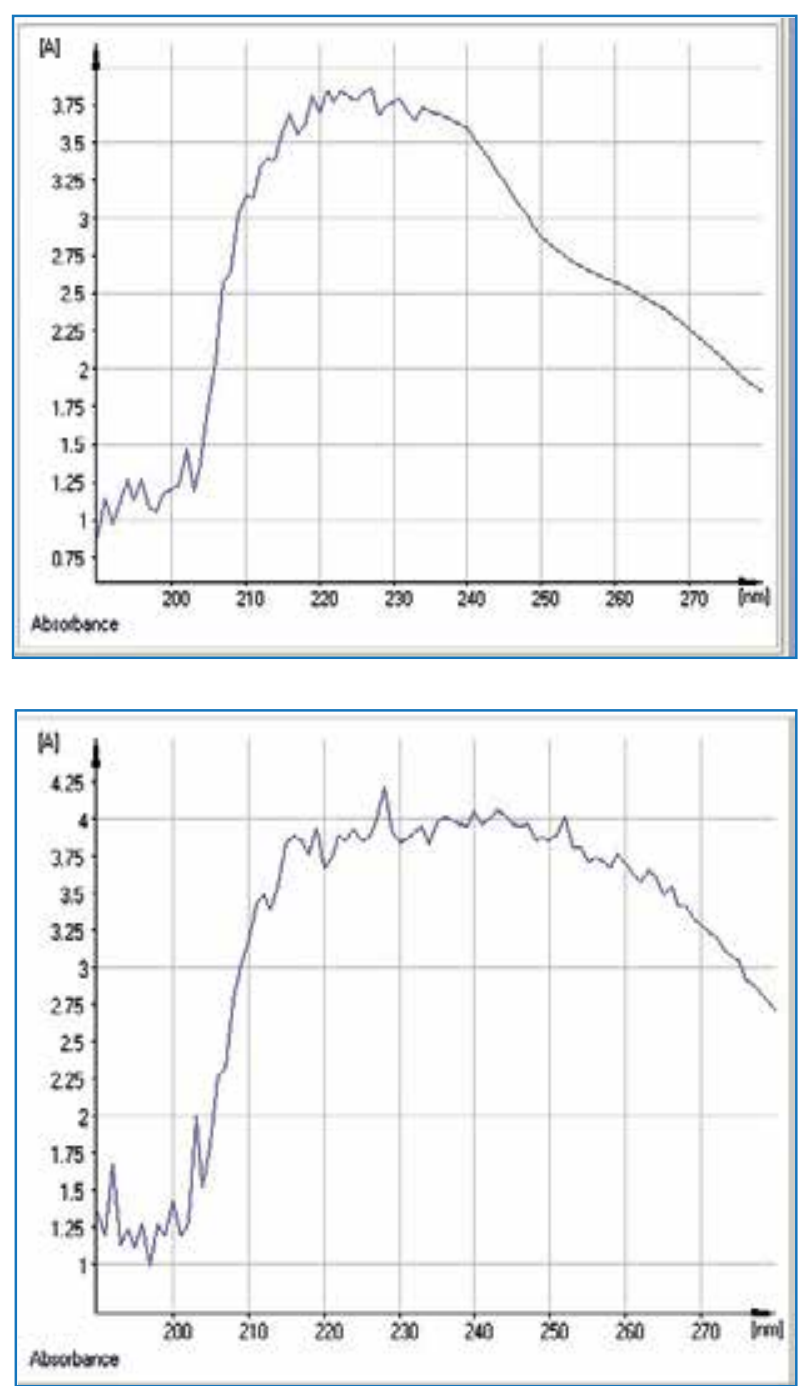

Fig. 1. UV absorption spectra of total hydrocarbon of petroleum hydrocarbon contaminated soil samples dissolved in hexane 
ranges from $1.6 \times 10^{3}$ to $3.75 \times 10^{3} \mathrm{CFU} / \mathrm{gm}$ at 72 hours. Diesel degrading ability was found in every isolate. The identification of bacteria was traditionally performed by means of cultural, morphological and Gram staining from a paddy soil microcosm that had been artificially contaminated with diesel oil and found that it can degrade diesel oil contained in liquid LB (Lauria-Bertani) media and MSM. Lawson et al., (2013), isolated six hydrocarbons

Table II. Total number of diesel degrading bacteria in the petroleum hydrocarbon contaminated soil samples collected from Noyarhat, Savar

\begin{tabular}{|c|c|c|}
\hline & No. of bacteria at $32{ }^{\circ} \mathrm{C}$ for & No. of bacteria at $32{ }^{\circ} \mathrm{C} \quad 72 \mathrm{~h}$ \\
\hline Sample ID & $48 \mathrm{~h}(\mathrm{CFU} / \mathrm{gm})$ & $(\mathrm{CFU} / \mathrm{gm})$ \\
\hline S-1 & $7 \times 10^{2}$ & $1.6 \times 10^{3}$ \\
\hline$S-2$ & $1.6 \times 10^{3}$ & $2.2 \times 10^{3}$ \\
\hline$S-3$ & $2.15 \times 10^{3}$ & $3.3 \times 10^{3}$ \\
\hline$S-4$ & $2.35 \times 10^{3}$ & $3.75 \times 10^{3}$ \\
\hline$S-5$ & $9.5 \times 10^{2}$ & $1.75 \times 10^{3}$ \\
\hline
\end{tabular}

techniques. Every isolate was creamy white color and round in shape. The size of the isolate was small. All the isolates were Gram negative (-), cocci shaped. Five isolates were selected for further studies.

The soil is a hospitable environment for all types of microorganisms. Naturally, soil is a variable mixture of minerals, organic matters and water which is capable of supporting microorganism's life (Manahan, 1992). But in this study, the number of bacteria isolated from the soil is not so high. The collected soil samples were hydrocarbon contaminated and only some resistant organisms could survive in this type of soil. The sampling period may be another reason for low survival.

\section{Effect of diesel concentration on growth of isolates}

To study the varying concentrations of diesel on the growth of the microorganisms, one of the potential isolates was incubated in a conical flask containing MSM with different concentrations of diesel (5\% to $25 \%$ ) and incubated at $32{ }^{\circ} \mathrm{C}$ under $100 \mathrm{rpm}$ for $24 \mathrm{~h}$. The effect of varying concentrations of diesel on the tolerance pattern of the microbial growth was measured by monitoring optical density (OD), using an optical spectrophotometer at $600 \mathrm{~nm}$. Fig. 2 illustrates the tolerance pattern of the isolate at $24 \mathrm{~h}$.

Bacterial isolate- 4 can successfully tolerate all types of tested concentration of diesel. At $24 \mathrm{~h}$, the maximum bacterial growth was found in $20 \%(\mathrm{v} / \mathrm{v})$ of diesel and the OD value was 1.31. The bacterial growth was increasing with increasing concentration of diesel but it was decreased at $25 \%$ of diesel. Ueno et al., 2007, isolated Rhodococcus sp. utilizing bacterial genera, Bacillus, Staphylococcus, Enterobacter, Yersinia, Proteus, and Alcaligenes and found that they are capable of degrading and utilizing diesel oil as carbon source. When natural environment is contaminated with pollutants, the indigenous microbial communities are likely to comprise microbial populations of different taxonomic characteristics, which are capable of degrading the contaminating chemicals (Ahmed et al., 2010).

Effect of various concentration of phenol on growth of bacteria

Fig. 3 shows degradation of various concentrations of phenol $(10-50 \mathrm{ppm})$ by potential bacterial isolate when grown in (MSM) at $32{ }^{\circ} \mathrm{C}$ at $100 \mathrm{rpm}$ for $24 \mathrm{~h}$. The concentration of phenol decreased with increasing bacterial growth and bacterial growth increasing with increasing time. Among the five types of concentrations of phenol (10 ppm to $50 \mathrm{ppm}$ ), bacteria could grow on all types of phenol concentrations. Maximum degradation of phenol was recorded at $48 \mathrm{~h}$. At 24 $\mathrm{h}$ and $48 \mathrm{~h}$ of incubation the maximum growth was found in $50 \mathrm{ppm}$ of phenol concentration and the minimum growth was recorded at $10 \mathrm{ppm}$ of phenol concentration. The growth of bacteria was decreased after $96 \mathrm{~h}$ of incubation as phenol availability reduced significantly.

Jame et al., (2010), used mixed culture of locally isolated Pseudomonas species for the degradation of phenol by using minimal media and found that all the isolates could completely degrade phenol up to $600 \mathrm{ppm}$. Tambekar et al., (2012), isolated phenol degrading bacteria from the alkaline Lonar Lake, India. They found that Staphylococcus species 


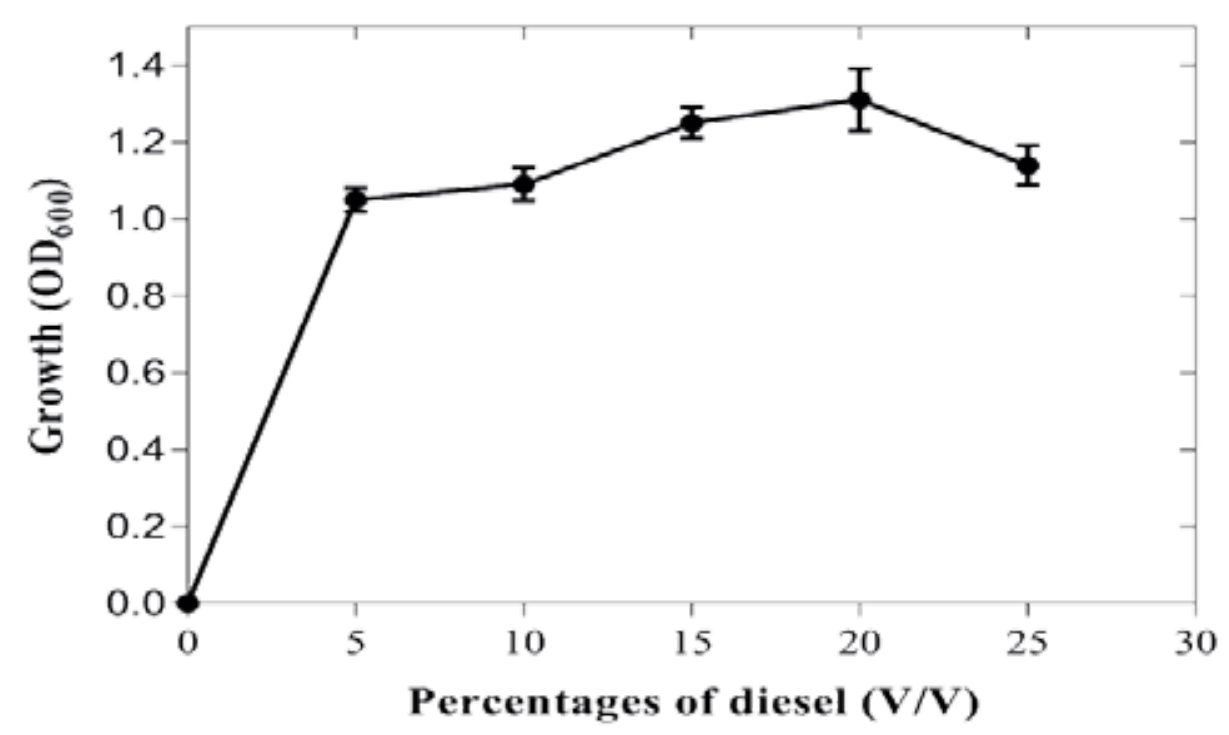

Fig. 2. Growth of bacterial isolate-4 when it was grown in Mineral Salt Media (MSM) containing various concentration of diesel at $32{ }^{\circ} \mathrm{C}$, at $100 \mathrm{rpm}$ for $24 \mathrm{~h}$

degrade $64 \%$ and $75 \%$ phenol in the peptone water phenol medium at laboratory level. Naresh et al., (2012) isolated a bacterial strain from effluent of a phenol contaminated site Ankleshwar, India and found that complete phenol biodegradation was achieved after 4 days in 1000 ppm solution. They used bacteria isolated from phenol contaminated effluent, so the bacteria had high potential of phenol biodegradation. But in the present study, bacteria were isolated from diesel contaminated soil. That's why the rate of phenol degradation is lower than the previous investigation by Naresh et al., (2012).

The growth of bacteria becomes very slow when they adapt to their new environment. After this phase, log phase started and bacterial growth increased at a high rate and after utilization of nutrients death phase started (Maier et al., 2009). From the figure, the growth of bacteria was low at 24 $\mathrm{h}$ which may be the lag phase of bacterial growth, but at $48 \mathrm{~h}$ the bacterial growth increased which can be indicated by the log phase. Bacterial growth started to decrease and death phase started at $96 \mathrm{~h}$. Bui et al., (2012), isolated aerobic bacteria which were highly effective for the removal of phenol. After 120 hours of culture, two bacterial strain degraded $54.84 \%$ and $44.19 \%$ phenol from the initial concentrations of $100 \mathrm{mg} / \mathrm{L}$ and $1000 \mathrm{mg} / \mathrm{L}$, respectively and another strain degraded $66.45 \%$ of phenol from the initial concentration of $1500 \mathrm{mg} / \mathrm{L}$.

\section{Effect of phenol and diesel on growth of isolates}

The effect of varying concentrations of both phenol and diesel on the microbial growth was measured by monitoring optical density (OD), using an optical spectrophotometer at $600 \mathrm{~nm}$. Table III shows bacterial growth with different concentrations of phenol and diesel. From the above table, it is clear that bacteria can grow in media which containing both diesel and phenol. Both of these hydrocarbons are utilized by bacteria as a carbon source. Ahamed et al., (2006), used MSM for isolation of diesel degrading bacteria and found that the highest $96.8 \%$ degradation of diesel was shown by Bacillus brevis, followed by $92 \%, 88.8 \%$ and $84.8 \%$ diesel degradation by the strains Pseudomonas alcaligenes, Bacillus cirroflagellosus and Citrobacter freundii, respectively. The microbial degradation of phenol by pure and mixed cultures of Pseudomonas putida was studied by Yang and Humphrey (1975). They found that phenol removal from wastewaters down to levels of 1-2 ppm should possible. Therefore, it can be concluded that the isolated bacteria have the potential to degrade both phenol and diesel and further can be used as other hydrocarbon degradation studies. 


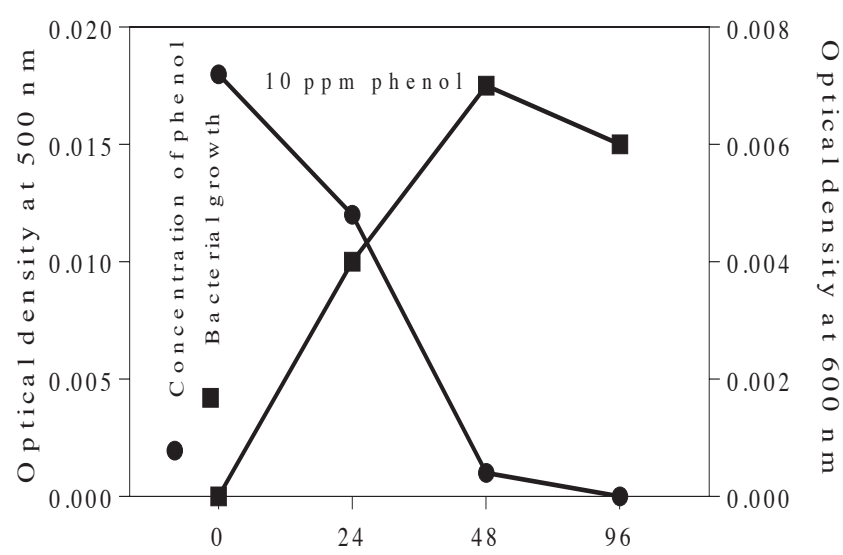

$\mathrm{T}$ im e (h)

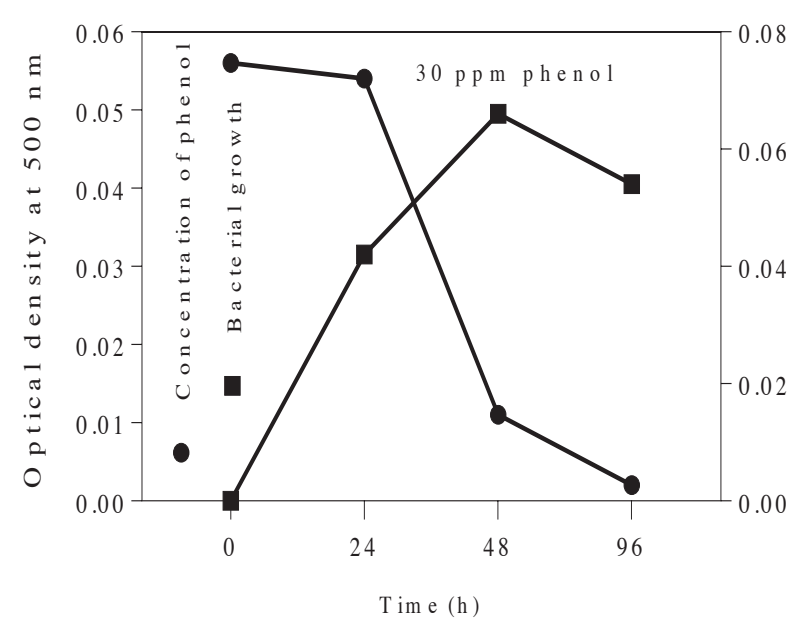

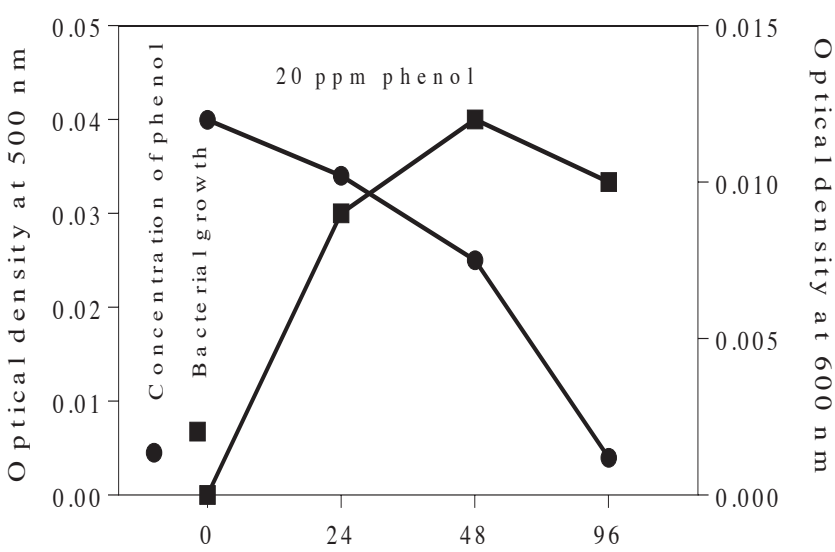

Time (h)

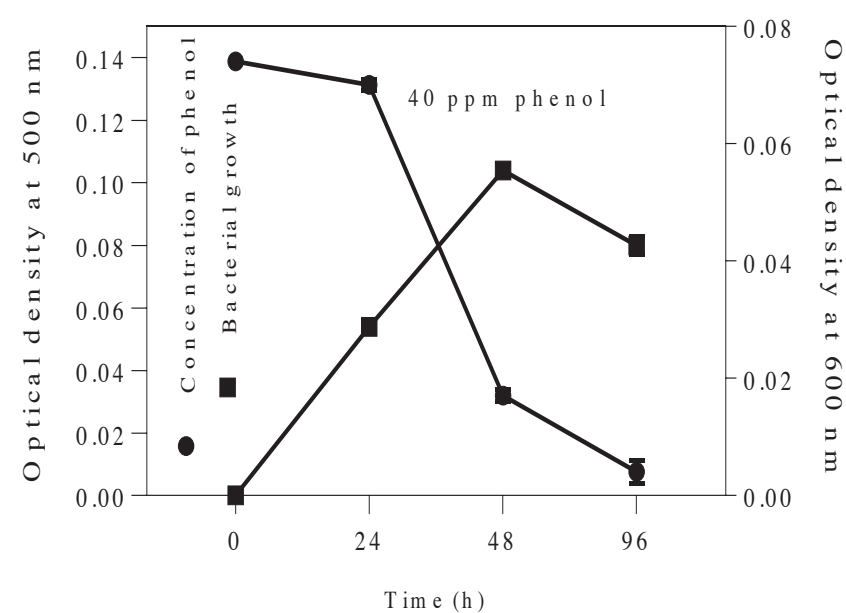

0
0
0
0
0
1
2
0
0
0
$\vdots$
4
0
0
0
0
0
3
3

Time (h)

Fig. 3. Growth of bacterial isolate-4 when it was grown in mineral salt media (MSM) containing various concentration of diesel at $32{ }^{\circ} \mathrm{C}$, at $100 \mathrm{rpm}$ for $24 \mathrm{~h}$ 
Table III. Growth of bacteria in MSM medium containing different concentration of diesel and phenol at $32^{\circ} \mathrm{C}$ for $48 \mathrm{~h}$

\begin{tabular}{|c|c|c|}
\hline \multicolumn{2}{|c|}{ Carbon sources for bacterial growth } & \multirow[t]{2}{*}{ Bacterial growth $\quad(\mathrm{OD}$ at $600 \mathrm{~nm})$} \\
\hline Phenol (ppm) & $\%$ Diesel $(\mathrm{V} / \mathrm{V})$ & \\
\hline 2.5 & 5.0 & 1.193 \\
\hline 2.5 & 10 & 1.109 \\
\hline 5.0 & 5.0 & 1.194 \\
\hline 5.0 & 10 & 1.06 \\
\hline
\end{tabular}

\section{Conclusion}

Petroleum hydrocarbon is somehow pilfering during transportation as oil spills and contaminates soil and water. The range of total number of diesel degrading bacteria in soil samples was $7 \times 10^{2} \mathrm{CFU} / \mathrm{gm}$ to $2.35 \times 10^{3}$ at 48 hours and $1.6 \times 10^{3}$ to $3.75 \times 10^{3} \mathrm{CFU} / \mathrm{gm}$ at 72 hours . Among five samples, microorganisms found in every sample and all the isolates are Gram negative, round and cocci shaped as identified by Gram staining. Five morphologically distinct colonies were purified, characterized and considered as diesel resistant. Phenol and diesel are degraded by using these microorganisms isolated from petroleum hydrocarbon contaminated soil. Among the tested diesel concentration, maximum growth of bacteria was obtained at $20 \%(\mathrm{v} / \mathrm{v})$ of diesel and beyond this concentration of diesel bacterial growth started to decrease at $24 \mathrm{~h}$. The potential isolate could completely degrade 50 ppm of phenol concentration after $96 \mathrm{~h}$ of incubation. Maximum growth was obtained at 48 hours. Bacteria can also be grown on media which containing both diesel and phenol. Therefore, these bacteria can be used for degradation of petroleum hydrocarbon contaminated environment.

\section{References}

Ahamed F, Hasibullah M, Ferdouse J and Anwar M N (2010), Microbial Degradation of Petroleum Hydrocarbon, Bangladesh Journal of Microbiology 27(1): 10-13.

Al-Sharidah A, Richardt A, Golecki JR, Dierstein R and Tadros MH (2000), Isolation and characterization of two Hydrocarbon-degrading Bacillus subtilis Strains from oil Contaminated Soil of Kuwait, Microbiological Research155 (3): 157-164.
Annadurai G, Ling L and Lee J (2007), Biodegradation of phenol by Pseudomonas pictorum on Immobilized with Chitin, African Journal of Biotechnology 6(3): 296-303.

APHA (1998), Standard Methods for the Examination of Water and Wastewater, American Public health association, 20 ${ }^{\text {th }}$ Edition, AWWA-APHA-WEF, Washington DC.

ArunKumar D and Anitha A (2014), Biodegradation of Phenol and Emulsification Properties of Native Microorganisms from Coal Carbonization Plant, International Journal of Applied Biology and Pharmaceutical Technology 5: 249-256.

Arutchelvan V, Kanakasabai V, Elangovan R, Nagarajan S and Muralikrishnan V (2006), Kinetics of High Strength Phenol Degradation Using Bacillus brevis, Journal of Hazardous Materials 129(1-3): 216-222.

Banerjjee A and Ghoshal AK (2010), Phenol Degradation by Bacillus cereus: Pathway and kinetic modeling, Bioresource Technology 101(14):5501-5507.

Banerjjee A. and Ghoshal AK (2010), Isolation and Characterization of Hyper Phenol Tolerant Bacillus $s p$. from Oil Refinery and Exploration sites, Journal of Hazardous Materials 176(1):85-91.

Binsadiq ARH (2014), Fungal Biodegradation of Diesel by Ulocladium Atrum, Journal of Emerging Trends in Engineering and Applied Sciences 5(5): 318-322.

Bui HB, Nguyen LT and Dang LD (2012), Biodegradation of Phenol by Native Bacteria Isolated From Dioxin Contaminated Soils, Journal of Bioremediation and Biodegradation 3: 1-6. 
Campos FM, Couto JA and Hogg TA (2002), Influence of Phenolic Acids on Growth and Inactivation of Oenococcus oeni and Lactobacillus hilgardii,Journal of Applied Microbiology 94:167-174.

Dhar K, Dutta S and Anwar MN (2014), Biodegradation of Petroleum Hydrocarbon by Indigenous Fungi isolated from Ship breaking yards of Bangladesh, International Research Journal of Biological Sciences 3(9):22-30.

El-Sayed WA, Ibrahim MK, Abu-Shady M, El-Beih F, Ohmura N, Saiki H and Ando A (2003), Isolation and Characterization of Phenol-catabolizing Bacteria from a Coking Plant, Bioscience Biotechnology and Biochemistry 67(9): 2026-2029.

Hong JH, Kim J, Choi OK, Cho K and Ryu HW(2004), Characterization of a Diesel-degrading Bacterium, Pseudomonas aeruginosa IU5, Isolated from Oil Contaminated Soil from Korea, World Journal of Microbiology and Biotechnology 21(3):381- 384.

Jame SA, Rashidul Alam AKM, Fakhruddin ANM, Alam MK (2010), Degradation of Phenol by Mixed Culture of Locally Isolated Pseudomonas Species, Journal of Bioremediation and Biodegradation 1:102.

Kebria DY, Khodadadi A, Ganjidoust H, Badkoubi A and Amoozegar MA (2009), Isolation and Characterization of a Novel Native Bacillus Strain Capable of Degrading Diesel Fuel, International Journal of Environmental Science and Technology 6 (3), 435-442.

Kucharski J, Tomkiel M, Boros E and Wyszkowska J (2010), The Effect of Soil Contamination with Diesel Oil and Petrol on the Nitrification process, Journal of Elementol 15: 111-118.

Lawson IYD, Afenu JK, Nartey EK and Quaye J (3013), Diesel Oil Utilizing Bacteria Associated with Four Ghanaian soils, Agriculture and biology of North America 4: 364-369.

Maier RM, Pepper IL and Gerba CP (2009) Environmental Microbiology, $2^{\text {nd }}$ Edition, Elesivier Inc, 30 corporate drive suite 400, Burlington, USA.

Manahan (1992), Toxicological Chemistry, $2^{\text {nd }}$ Edition, Lewis Publishers. 121 ,South main street, Michigan, USA.
Miranda R, Souza CS, Gomes EB, Lovaglio R, Lopes C. and Sousa M (2007), Biodegradation of Diesel Oil by Yeasts Isolated from the Vicinity of Suape Port in the State of Pernambuco -Brazil, Brazilian Archives of biology and technology 50 (1): 147-152.

Naresh B, Honey P and Vaishali S (2012), Biodegradation of Phenol by a Bacterial Strain Isolated From a Phenol Contaminated Site in India, International Research Journal Environmental Sciences 1(1): 46-49 (2012).

Saadoun I (20002), Isolation and Characterization of Bacteria from Crude Petroleum Oil Contaminated Soil and their Potential to Degrade Diesel Fuel, Journal of Basic Microbiology 42 (5):422-430.

Singh C, and Lin J (2008), Isolation and Characterization of Diesel Oil Degrading Indigenous Microorganisms in Kwazulu-Natal, South Africa, African Journal of Biotechnology 7(12): 1927-1932.

Tambekar DH, Tale SD and Borkar PR (2012), Bioremediation of Phenol by Haloalkaliphilic Microorganisms Isolated from Lonar Lake, International Journal of Science, Environment and Technology 2:434 - 441 .

Tambeker DS, Bhorse PS and Gadakh PV (2012), Biodegradation of Phenol by Native Microorganisms Isolated from Lonar Lake in Maharashtra State (India), International Journal of Life Science and Pharmaceutical Research 2:26-30.

Ueno A, Ito Y, Yumoto I and Okuyama H (2007), Isolation and Characterization of Bacteria from Soil contaminated with Diesel Oil and the Possible use of these in Autochthonous Bioaugmentation, World Journal of Microbiology and Biotechnology 23(2): 1739-1745.

UK HPA (2006), Compendium of Chemical Hazards: Diesel. Health Protection Agency HPA Prepared by: Robert P Chilcott Chemical Hazards and Poisons Division (HQ), Chilton, Didcot, Oxfordshire, OX11 ORQ, United Kingdom.

Usha P, Rama Bhat P, Prajna PS, Shetty S, Jayadev K and Jenitta E (2015), Degradation of Petroleum by Microorganisms Isolated from Oil Contaminated with Petrol and its Byproducts, International Journal of emerging engineering applications and bio-sciences 2(1): 66-81. 
Wang J, Zhan X, Liang J, Zhou L, Lin Y and Wong J (2011), A Novel Method for the Determination of Total Hydrocarbon in the Hydrocarbon Mixture-contaminated Soil, Bioremediation and Biodegradation S2: 1-6.
Yang RD and Humphrey AE (1975), Dynamic and Steady State Studies of Phenol Biodegradation in Pure and Mixed Cultures, Biotechnology and bioengineering 17(8): 1211-1235. 